\title{
REVERSION BY CALCIUM OF A YEAST-LIKE DEVELOPMENT TO THE ORIGINAL FILAMENTOUS FORM, OF THE 10V10 5-FLUOROCYTOSINE-SENSITIVE MUTANT OF ASPERGILLUS NIGER
}

\author{
Rosangela de Carvalho Goulart ${ }^{1}$; José Moacir Marin ${ }^{2 *}$ \\ ${ }^{1}$ Faculdade de Ciências Agrárias e Veterinárias, Universidade Estadual Paulista, Jaboticabal, SP, Brasil; ${ }^{2}$ Departamento de \\ Morfologia, Estomatologia e Fisiologia, Faculdade de Odontologia de Ribeirão Preto, Universidade de São Paulo, Ribeirão \\ Preto, SP, Brasil
}

Submitted: June 01, 2004; Returned to authors for corrections: July 18, 2005; Approved: September 12, 2005

\begin{abstract}
Some filamentous fungi present the phenomenon of dimorphism, their morphological structure alterations being capable of inducing metabolism changes. The Aspergillus niger strain 10v10, a producer of citric acid, was submitted to the mutagenic action of ultraviolet irradiation which respectively selects mutants sensitive or resistant to the antifungi agent 5 fluorocytosine (5-FC). 5-FC sensitive mutants presented a morphological alteration to a yeast-like form. The effects of $\mathrm{pH}$ changes, addition of salts $\left(\mathrm{KH}_{2} \mathrm{PO}_{4}, \mathrm{NH}_{4} \mathrm{NO}_{3}, \mathrm{MgSO} 4\right.$ and $\mathrm{MgCl}_{2}$ ), the presence of osmotic stabilizers, as well as of calcium chloride, on morphological reversal and acid production were studied. Morphological reversal to the filamentous form was observed only in the presence of $\mathrm{CaCl}_{2}(500 \mathrm{mM})$ for the mutants strains 1 and 2, while the acid production occurred in both, yeast-like and filamentous forms.
\end{abstract}

Key words: Aspergillus niger, 5-fluorocytosine, yeast-like, calcium, acid production, dimorphism

\section{INTRODUCTION}

Some fungi are dimorphic, presenting two morphological forms, filamentous or yeast-like depending on environmental factors, fungal physiological condition or the fungal genome. They include saprobic forms such as Mycotypha sp, Aspergillus parasiticus and Mucor sp, as well as several important mammalian pathogens such as Blastomyces dermatidis, Histoplasma capsulatum and Sporothrix schenkii $(9,11)$.

Aspergillus niger is a filamentous fungus of high industrial value due to its use in the manufacture of citric acid; it is utilized among others, by the pharmaceutical, alimentary and cosmetic industries. The 10v10 strain of Aspergillus niger has been utilized as a producer of citric acid in surface fermentation processes (2).

Microorganisms deficient in protein synthesis, supply citric acid in higher yields. A frequently utilized technique to promote that deficiency is the employment of antibiotics or antimicotics to obtain protein synthesis resistant, or sensitive microorganism (20). In the presence of cytosine, the antimicotic drug 5fluorocytosine (5-FC) is carried in to the cell's interior, altering protein and DNA synthesis $(5,7)$.

During the process of selection of 5-FC sensitive mutants, the appearance of yeast-like characteristics among these mutants was noted. The objective of the present work was to evaluate the reversal to the filamentous form of such mutants, and the possible influence of this change on citric acid production.

\section{MATERIALS AND METHODS}

\section{Microorganism}

Aspergillus niger 10v10, a local citric acid producer used in a surface fermentation process by the industry in the past, kindly supplied by Dr. João Lucio de Azevedo - Escola Superior de Agricultura Luiz de Queiroz/USP, was used as the parental strain to obtain mutants, studied in the present work.

*Corresponding Author. Mailing address: Departamento de Morfologia, Estomatologia e Fisiologia - USP, Faculdade de Odontologia de Ribeirão Preto, Campus USP, Via do Café, s/n. 14040-904, Ribeirão Preto, SP, Brasil. Fax: (+5516) 633-0999. E-mail: jmmarin@ forp.usp.br 


\section{Culture media}

Dextrose Sabouraud Agar at 4\% (SB 4\%) was utilized for strain maintenance. FCL medium (20) containing (g/L): glucose120 , ammonium sulfate-3.0, monobasic potassium phosphate-1.0, dibasic potassium phosphate-1.0, magnesium sulfate- 0.5 , manganese sulfate- 0.014 , ferric chloride- 0.01 , was utilized. The $\mathrm{pH}$ was initially adjusted to 3.0, with hydrochloric acid. For the isolation of sensitive or resistant mutants to 5-FC, the FCL medium was supplemented with $5-\mathrm{FC}(0.1 \mu \mathrm{g} / \mathrm{mL})$. The $4 \%$ SB medium was also employed to verify the effects of salts and osmotic stabilizers ( $\mathrm{KCl}, \mathrm{MgSO}_{4}$ and Sorbitol); to study the effect of calcium on the morphology, $500 \mathrm{mM} \mathrm{CaCl}_{2}$ was added to the medium.

\section{Mutagenesis of the parental strain of $A$. niger $10 \mathrm{~V} 10$}

Briefly, conidia from 5-7 day old colonies were collected in Tween 80 solution $(0.1 \% \mathrm{v} / \mathrm{v})$ and the suspension adjusted to $10^{6} / \mathrm{mL}$ with saline $(\mathrm{NaCl} 0.85 \% \mathrm{w} / \mathrm{v}) ; 0.5 \mathrm{~mL}$ of the conidia suspension plus $9.5 \mathrm{~mL}$ of saline was put on a Petri dish and submitted to ultraviolet light treatment (Philips TUV,15w,254nm) for $15 \mathrm{~min}$. under magnetic agitation as described before (12). Ten $\mathrm{mL}$ of the irradiated suspension were inoculated into $50 \mathrm{~mL}$ of FCL/ 5-FC medium, in $250 \mathrm{~mL}$ Erlenmeyer flasks, and incubated for $72 \mathrm{~h}$ in a water bath, at $30^{\circ} \mathrm{C}$, with a $125 \mathrm{rpm}$ shaking movement, as described before (20). After each $24 \mathrm{~h}$ period, the FCL/5-FC was filtered through glass wool, so that the conidia that had germinated in the presence of 5-FC, would remain in the glass wool to be seeded into the SB/ 5-FC medium. Nongerminated conidia, considered sensitive, were collected from the filtrate; following centrifugation at $10,000 \mathrm{~g}$ for $2 \mathrm{~min}$, they were washed with sterile distilled water, suspended in $0.5 \mathrm{~mL}$ of the FCL medium and re-inoculated into $50 \mathrm{~mL}$ of the FCL/5-FC medium. After completing the 72-h incubation period, the filtrate containing the sensitive conidia was seeded on Petri dishes containing the SB medium, to obtain isolated colonies.

\section{Confirmation of sensitivity or resistance of selected A. niger mutants}

Isolated mutants showing yeast-like morphology were inoculated into the $4 \% \mathrm{SB}$ medium containing $5-\mathrm{FC}(0.1 \mu \mathrm{g} / \mathrm{mL})$ and incubated for $48 \mathrm{~h}$ at $30^{\circ} \mathrm{C}$. SB medium without 5-FC, was utilized to evaluate fungi growth. Mutants showing only growth in the 5-FC-free medium were considered to be sensitive to the drug; mutants presenting growth in both SB 4\% 5-FC containing and 5-FC-free media were considered to be resistant to the drug. All mutants chosen were maintained on SB $4 \%$ plates at $4^{\circ} \mathrm{C}$, following the $48 \mathrm{~h}, 30^{\circ} \mathrm{C}$ growth period.

\section{Effect of pH alteration on chosen mutant strains}

Selected yeast-like mutant strains were seeded in 4\% SB and the medium $\mathrm{pH}$ adjusted with $0.5 \mathrm{M} \mathrm{HCl}$ or $0.5 \mathrm{M} \mathrm{NaOH}$ to evaluate growth at $\mathrm{pH} 4,6$ and 8 , respectively. Yeast-like mutants were inoculated and incubated at $37^{\circ} \mathrm{C}$ for 48 hours.
Effect of the addition of $\mathrm{NH}_{4} \mathrm{NO}_{3}, \mathrm{MgSO}_{4}, \mathrm{MnCl}_{2}$ and $\mathrm{KH}_{2} \mathrm{PO}_{4}$

Different salts were added at different concentrations to the $4 \% \mathrm{SB}$ plated medium as follows: $\mathrm{NH}_{4} \mathrm{NO}_{3}(0.4 ; 0.8 ; 1.2 ; 1.6 ; 2.0$; $2.4 \mathrm{~g} / \mathrm{L}) ; \mathrm{MgSO}_{4}(0.01 ; 0.02 ; 0.03 ; 0.04 ; 0.05 ; 0.06 \mathrm{~g} / \mathrm{L})$; $\mathrm{MnCl}_{2}(0.012 ; 0.018 ; 0.024 ; 0.030 ; 0.036 ; 0.048 \mathrm{mg} / \mathrm{L})$ and $\mathrm{KH}_{2} \mathrm{O}_{4}(0.2 ; 0.4 ; 0.8 ; 1.0 ; 1.2 ; 1.4 \mathrm{~g} / \mathrm{L})$. The yeast-like strains were inoculated into dishes containing the various salt concentrations, incubated at $30^{\circ} \mathrm{C}$ and their growth followed for $72 \mathrm{~h}$.

\section{Addition of osmotic stabilizers to the culture medium}

The three osmotic stabilizers, $\mathrm{KCl} 0.6 \mathrm{M}, \mathrm{MgSO}_{4} 1.2 \mathrm{M}$ and Sorbitol 1.2 M, were added to the culture medium and the plates incubated with the yeast-like mutant strain for $72 \mathrm{~h}$ at $30^{\circ} \mathrm{C}$.

\section{Effect of $\mathrm{CaCl}_{2}$}

The yeast-like mutant strains were inoculated into $100 \mathrm{~mL}$ of the FCL medium containing $500 \mathrm{mM} \mathrm{CaCl}_{2}$ in $250 \mathrm{~mL}$ Erlenmeyer flasks, and incubated at $30^{\circ} \mathrm{C}$, with a $125 \mathrm{rpm}$ shaking motion for nine days. The flasks with the cultures were then kept in the laboratory for further observation.

\section{Citric fermentation, determination of titratable acidity and dry weight of the mycelia}

Fermentation to citric acid was performed on a laboratory scale by the submerse procedure, using $250 \mathrm{~mL}$ Erlenmeyer flasks, containing $100 \mathrm{~mL}$ of the $\mathrm{FCL}$ culture medium, at $30^{\circ} \mathrm{C}$, with constant shaking at $125 \mathrm{rpm}$, for nine days, in a Dubnoff bath. Following this period of fermentation, the biomass formed was separated from the liquid medium by filtration, washed with distilled water, and maintained in an oven at $98^{\circ} \mathrm{C}$ for $24 \mathrm{~h}$; following drying, it was weighed to obtain the weight of the mycelia (16), The determination of the total acidity produced was made by titration with $0.1 \mathrm{~N} \mathrm{NaOH}$ and a phenolphthalein indicator (20).

\section{RESULTS}

Mutagenesis induced by ultraviolet irradiation of the conidia of the parental strain A. niger 10v10, and the inoculation into liquid FCL media containing 5-FC, permitted the isolation of eight mutants of strain 10v10, presenting wrinkled, brain-like colonies with a creamy-like consistency. After secondary subculture, the colonies presented growing bright, smooth, white mucoid aspect, denominated yeast-like. They were classified as 5-FC-sensitive. Nine 5-FC-resistant, filamentous mutants, of sporulated, dark brown to black colored colonies, showing morphological characteristics similar to those of the parental strain of A. niger 10v10, were also isolated, but not utilized in the present work.

The yeast-like mutant strains, were kept in 4\% SB medium, and analyzed for the effects of $\mathrm{pH}$ changes, addition of salts, of osmotic stabilizers or $\mathrm{CaCl}_{2}$, as shown on Table 1 . 
Table 1. Evaluation of the morphological effect of different agents which promote metabolic alterations in the morphology of the yeast-like mutants ( 1 to 8 ) from the 10v10 A. niger parental strain.

\begin{tabular}{|c|c|c|c|c|}
\hline \multicolumn{2}{|c|}{ Agents } & \multicolumn{3}{|c|}{ Morphological alteration } \\
\hline & & \multicolumn{2}{|c|}{ Growth } & \multirow[t]{2}{*}{ Reversal } \\
\hline & & + & - & \\
\hline \multirow[t]{3}{*}{$\mathrm{pH}$} & 4.0 & $1,2,3,4,5,6,7,8$ & - & - \\
\hline & 6.0 & $1,2,3,4,5,6,7,8$ & - & - \\
\hline & 8.0 & $1,2,3,4,5,6,7,8$ & - & - \\
\hline \multirow{6}{*}{$\begin{array}{c}\mathrm{NH}_{4} \mathrm{NO}_{3} \\
(\mathrm{~g} / \mathrm{L})\end{array}$} & 0.4 & $2,4,5,7$ & $1,3,6,8$ & - \\
\hline & 0.8 & $2,4,5,7$ & $1,3,6,8$ & - \\
\hline & 1.2 & $2,4,5,7$ & $1,3,6,8$ & - \\
\hline & 1.6 & $2,4,5,7$ & $1,3,6,8$ & - \\
\hline & 2.0 & $2,4,5,7$ & $1,3,6,8$ & - \\
\hline & 2.4 & $1,2,3,4,5,6,7,8$ & - & - \\
\hline \multirow{6}{*}{$\underset{(\mathrm{g} / \mathrm{L})}{\mathrm{MgSO}_{4}}$} & 0.01 & $2,5,7$ & $1,3,4,6,8$ & - \\
\hline & 0.02 & $2,5,7$ & $1,3,4,6,8$ & - \\
\hline & 0.03 & $2,5,7$ & $1,3,4,6,8$ & - \\
\hline & 0.04 & $2,5,7$ & $1,3,4,6,8$ & - \\
\hline & 0.05 & $2,5,7$ & $1,3,4,6,8$ & - \\
\hline & 0.06 & $2,5,7$ & $1,3,4,6,8$ & - \\
\hline \multirow{6}{*}{$\begin{array}{c}\mathrm{KH}_{2} \mathrm{PO}_{4} \\
(\mathrm{~g} / \mathrm{L})\end{array}$} & 0.2 & 2,5 & $1,3,4,6,7,8$ & - \\
\hline & 0.4 & 2,5 & $1,3,4,6,7,8$ & - \\
\hline & 0.8 & 2,5 & $1,3,4,6,7,8$ & - \\
\hline & 1.0 & 2,5 & $1,3,4,6,7,8$ & - \\
\hline & 1.2 & 2,5 & $1,3,4,6,7,8$ & - \\
\hline & 1.4 & 2,5 & $1,3,4,6,7,8$ & - \\
\hline \multirow{6}{*}{$\begin{array}{c}\mathrm{MnCl}_{2} \\
(\mathrm{~g} / \mathrm{L})\end{array}$} & 0.012 & $1,2,3,4,5,6,7,8$ & - & - \\
\hline & 0.018 & $1,2,3,4,5,6,7,8$ & - & - \\
\hline & 0.024 & $1,2,3,4,5,6,7,8$ & - & - \\
\hline & 0.030 & $1,2,3,4,5,6,7,8$ & - & - \\
\hline & 0.036 & $1,2,3,4,5,6,7,8$ & - & - \\
\hline & 0.048 & $1,2,3,4,5,6,7,8$ & - & - \\
\hline KCL & $0.6 \mathrm{M}$ & $1,2,3,4,5,6$ & 7,8 & - \\
\hline $\mathrm{MgSO}_{4}$ & $1.2 \mathrm{M}$ & 1,5 & $2,3,4,6,7,8$ & - \\
\hline Sorbitol & $1.2 \mathrm{M}$ & $1,2,5,6,7$ & $3,4,8$ & - \\
\hline $\mathrm{CaCl}_{2}$ & $500 \mathrm{mM}$ & $3,4,5,6,7,8$ & - & 1,2 \\
\hline
\end{tabular}

Mutants strains 1, 2, 5 and 6 were selected to be photographed under the optical microscope during the four following months. Added at a 500-mM concentration, $\mathrm{CaCl}_{2}$ promoted morphological reversion of the yeast-like mutant strains 1 and 2, to the filamentous condition. As it can be observed in Fig. 1- a, b, c and d both strains initially showed globular cells, subsequent budding characteristic of the yeastlike state, and finally cell grouping and formation of hyphae, characterizing the filamentous original fungus.
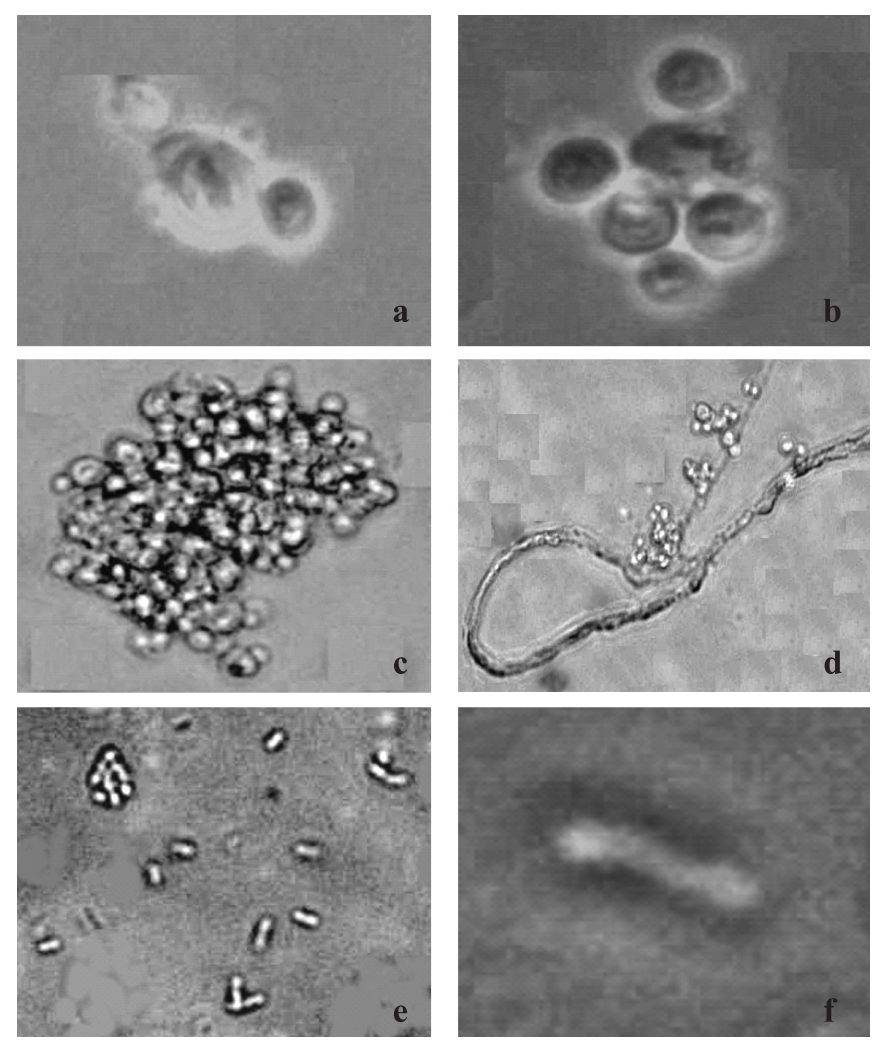

Figure 1. Visualization under the optic microscope: a) globose, yeast-like cell (1000x); b) cell grouping (1000x); c) cell grouping (40x); d) hyphae formation (400x); e) morphological aspect of strain 5 (400x); f) morphological aspect of strain 5 (1000x).

Mutant strains 5 and 6 presented a microscopic appearance, which remained unchanged during the four months of the photographic follow- up. The cylindrical cell aspect can be seen on Fig. 1 (e and f).

The parental strain of A. niger 10v10 was developed to be utilized in processes of surface fermentation (2). In the present work, the submerged fermentation process was utilized, the parental strain serving as control. After nine days of fermentation, the dry weight of the mycelium of each mutant yeast-like strain and the accumulation of the titratable acidity produced, were measured (Table 2). Only the four selected mutants $(1,2,5,6)$ were evaluated.

The yield of acid produced by the strains which underwent morphological reversal from the yeast-like to the filamentous form, was greater in the filamentous form for mutant 1 than in the yeast-like form and smaller in the filamentous form for mutant 2 than in the yeast-like form (Table 2). The dry weight of strain 1 presented only a slight variation according to their morphological state however, strain 2 when in the filamentous form, showed a significant increase in dry weight (Table 2). 
Table 2. Determination of mycelial dry weight and acid production by yeast-like mutant strains which underwent reversion from the yeast-like to the filamentous state in the presence of $500 \mathrm{mM} \mathrm{CaCl}_{2}$, and of the parent strain of A niger 10v10.

\begin{tabular}{|c|c|c|c|c|c|c|}
\hline \multirow{3}{*}{ Strain } & \multicolumn{6}{|c|}{ Morphological state of the culture } \\
\hline & \multicolumn{3}{|c|}{ Yeast-like } & \multicolumn{3}{|c|}{ Filamentous } \\
\hline & $\begin{array}{l}\text { Dry weight } \\
\text { g/L }\end{array}$ & $\begin{array}{l}\text { Acid production } \\
\mathrm{mmol} \mathrm{H}^{+} / \mathrm{L}\end{array}$ & $\begin{array}{l}\mathrm{mmol} \mathrm{H}^{+} / \mathrm{g} \\
\text { dry weight }\end{array}$ & $\begin{array}{c}\text { Dry weight } \\
\text { g/L }\end{array}$ & $\begin{array}{c}\text { Acid } \mathrm{mmol} \\
\text { production } \mathrm{H}^{+} / \mathrm{L}\end{array}$ & $\begin{array}{l}\mathrm{mmol} \mathrm{H}^{+} / \mathrm{g} \\
\text { dry weight }\end{array}$ \\
\hline 1 & 1.301 & 59 & 45.38 & 1.349 & 80 & 59.70 \\
\hline 2 & 1.170 & 32 & 27.35 & 11.682 & 97 & 8.30 \\
\hline 3 & 1.043 & 48 & - & - & - & - \\
\hline 4 & 1.090 & 34 & - & - & - & - \\
\hline 5 & 1.398 & 33 & 23.74 & - & - & - \\
\hline 6 & 0.960 & 28 & 29.16 & - & - & - \\
\hline 7 & 0.411 & 30 & - & - & - & - \\
\hline $8^{*}$ & - & - & - & - & - & - \\
\hline $10 \mathrm{v} 10$ & - & - & - & 7.209 & 155 & 21.52 \\
\hline
\end{tabular}

* Mutant strain 8 did not show enough growth.

\section{DISCUSSION}

Studies of great importance, involving pathogenic fungi have been centered on the investigation of dimorphism, employing the technique of inducing hyphae growth and examination of one or more of their specific properties $(1,3)$. Factors inducing hyphae development of $C$. albicans are quite varied, and include $\mathrm{pH}$, minerals, vitamins, amino acids and carbohydrates (11). The $\mathrm{pH}$ and temperature activate genetic elements related to fungi morphology, that regulate the formation of either yeast-like, or filamentous forms. Yeast-like cells of C. albicans grow at $\mathrm{pH} 4.5$ and $25^{\circ} \mathrm{C}$, while filamentous growth is induced by $\mathrm{pH} 6.8$ at $37^{\circ} \mathrm{C}$. Penicillium marnefei grows in culture at $25^{\circ} \mathrm{C}$ on Sabouraud agar as a mycelial fungus, typical of the genus; however, it shows yeast-like cells when growing at $37^{\circ} \mathrm{C}$ in vitro on appropriate media, or in vivo in infected animals and humans (19).Generally, in vitro conditions used to induce hyphae formation require a $\mathrm{pH}$ close to neutrality $(3,19)$.

Change of $\mathrm{pH}$ to 4,6 or 8 , and of temperature to $37^{\circ} \mathrm{C}$, tested in this work, did not yield filamentous development by mutant yeast-like strains of $A$. niger $10 \mathrm{v} 10$; this does not agree with the results obtained by others $(3,19)$, that verified the expression of morphology changes associated to $\mathrm{pH}$.

No morphological reversal was observed by us in the presence of various concentrations of $\mathrm{MgSO}_{4}, \mathrm{MnCl}_{2}$ or $\mathrm{KH}_{2} \mathrm{PO}_{4}$, that permitted yeast-like development of the strains studied. The salts tested are related to the yield of citric acid production and some morphological changes of the fungi, observed in their presence or absence. Several authors $(4,13,21,22)$ have verified such morphological alterations.
Osmotic stabilizers are widely used to maintain protoplasm integrity following the removal of the cell wall. Among the most common ones utilized, are inorganic salts, sugars and sugar alcohols. In general, inorganic salts have been proven to be most efficient for yeasts (24). In the presently studied mutant strains, $\mathrm{KCl}$, Sorbitol and $\mathrm{MgSO}_{4}$, useful as osmotic stabilizers, did not lead to morphological reversion.

Detroy and Ciegler (4), verified hyphae - yeast-like dimorphism in Aspergillus parasiticus in respectively, the presence or absence of manganese ions in the culture medium, observing also that the addition of amino acids, vitamins, and traces of other metals did not induce significant effects on morphogenetic development. The cultures were mostly yeastlike in the presence of $7.3 \times 10^{-4} \mathrm{mM}$ manganese; however, high manganese concentrations resulted in hyphae formation.

Calcium is an important element for growth, metabolism and differentiation of several fungi and yeasts $(6,23)$. It participates in multiple regulatory functions including sporulation, ramification, tip growth and hyphae reorientation, direction of localized stimuli, bud germination, regulation of dimorphism, sexual reproduction and control of the cell cycle has been described (23). At high concentration, calcium is toxic; for this reason, cells utilize a complex homeostatic system to maintain low levels of calcium concentration (6).

Pera and Callieri (18), verified that the addition of $0.5 \mathrm{~g} / \mathrm{L}$ of $\mathrm{CaCl}_{2}$ to the culture medium, promoted an increase in mycelium ramification in the filamentous strain of $A$. niger. The presence of short and tall ramifications of the hyphae, stimulated pellet formation, as it was also observed by others $(10,15)$.

Madi et al. (14) studied the effect of the addition of calcium to cultures of Aureobasidium pullulans, In the presence of low 
$\mathrm{Ca}^{2+}$ concentrations, increased formation of yeast-like cells and reduced morphology transition were observed. When the concentration of $\mathrm{Ca}^{2+}$ was raised, the development of a 3-4 mm diameter pellet was observed, with a predominance of filamentous development. In the present study, $500-\mathrm{mM} \mathrm{CaCl}_{2}$ induced the formation of hyphae in yeast-like mutant strains of A. niger 10v10. It must be observed that the induction of yeastlike mutants was found only for the 10v10 strain; other strains like N402 (8) did not show this effect after the same treatment, even if repeated several times.

A long time interval, of approximately 120 days, was required to obtain the yeast-like reversion to filamentous form, as also observed by Paula et al.(17) who, in their experiments, obtained morphological reversion of Scopulariosis brevicaulis after a two-month period of cultivation. This indicated that the strains remained for a long time in a transition state, of partial reversal. In the present study, strains 5 and 6 did not show reversal after four months, indicating that their morphological stability remained in a transition phase between filament and yeast, as also previously verified (17).

5-FC employed in chemotherapy of systemic candidiasis, interferes with nucleic acid synthesis. It is taken into fungal cells by a cytosine permease, deaminated to 5-fluorouracil, converted to the nucleosideo triphosphate and incorporated into RNA, where it causes miscoding. In addition, 5-FC is converted to deoxynucleoside, which inhibits thymidylate synthase and thereby DNA biosynthesis (7).However, there still exist doubts about its side effects.

Acid production, a characteristic of the A. niger 10v10 strain, was found both in the yeast-like mutants, and in the revertant filamentous form (Table 2).

In summary, this study shows the induction of the yeastlike development in A. niger strain 10v10 and its reversion to filamentous morphology in some mutants, in the presence of $500 \mathrm{mM}$ calcium chloride.

\section{ACKNOWLEDGEMENT}

The authors thank the National Council for Technological Development- CNPq, Brazil, for a scholarship to R.C.G.

\section{RESUMO}

\section{Reversão pelo cálcio de um desenvolvimento leveduriforme para a forma filamentosa original em um mutante sensível a 5-fluorocitosina na linhagem $10 \mathrm{~V} 10$ de Aspergillus niger}

Alguns fungos filamentosos apresentam o fenômeno de dimorfismo, sendo que as alterações da estrutura morfológica podem induzir alterações metabólicas. A linhagem de Aspergillus niger 10v10, produtora de ácido cítrico foi submetida à ação mutagênica da radiação ultravioleta selecionando mutantes sensíveis ou resistentes ao antifúngico 5-fluorocitosina (5-FC). Os mutantes selecionados como sensíveis a 5-FC apresentaram uma alteração morfológica com desenvolvimento leveduriforme. Nestes mutantes foram avaliados o efeito da alteração de $\mathrm{pH}$, a adição de sais $\left(\mathrm{KH}_{2} \mathrm{PO}_{4}, \mathrm{NH}_{4} \mathrm{NO}_{3}, \mathrm{MgSO}_{4} \mathrm{e} \mathrm{MnCl}_{2}\right)$, a presença de estabilizadores osmóticos, cloreto de cálcio, e o seu efeito sobre a reversão morfológica e a produção de ácido. A reversão morfológica para a forma filamentosa ocorreu apenas na presença de $\mathrm{CaCl}_{2}(500 \mathrm{mM})$ para as linhagens mutantes 1 e 2 , enquanto que a produção de ácido ocorreu nas duas formas, leveduriforme e filamentosa.

Palavras-chave: Aspergillus niger, 5-fluorocitosina, leveduriforme, cálcio, produção de ácido, dimorfismo

\section{REFERENCES}

1. Blas, G.S. Fungi pathogenic to humans: molecular aspects of dimorphism. In: Orora, D.K.; Ajello, L.; Mukurji, K.J. (Ed) Handbook of applied mycology, humans, animals and insect., v.2 New York: Marcel Dekker, 1991.

2. Bonatelli Jr., R; Azevedo, J.L.; Valent, G.U. Parasexuality in a citric acid producing strains of Aspergillus niger. Rev. Brasil. Genet., 6(30), 399-405, 1983

3. Buffo, J.; Herman, M.A.; Soll, D.R. A characterization of pH-regulated dimorphism in Candida albicans, Mycopathology, 85(1-2), 21-30, 1984

4. Detroy, R.W.; Ciegler, A. Induction of yeastlike development in Aspergillus parasiticus. J. Gen. Microbiol., 65, 259-264, 1971.

5. Diasio, R.B.; Benett, J.E.; Myers, C.E. Mode of action of 5fluorocytosine. Biochem. Pharmacol, 27, 703-707, 1978.

6. Gadd, G.; Brunton, A.H. Calcium involvement in dimorphism of Ophiostoma ulmi, the dutch elm disease fungus, and characterization of calcium uptake by yeast cells and germ tubes. J. Gen. Microbiol., 138, 1561-1571, 1992 .

7. Georgopapadakou, N.H.; Walsh, T.J. Antifungal agents: chemotherapeutic targets and immunologic strategies. Ant. agents Chemoth., 40(2), 279-291, 1996.

8. Goosen, T.; Bloemheuvel, G.; Gysler, C.; Bie, D.A.; van den Broek, H.W.J.; Swart, K. Transformation of Aspergillus niger using the homologous orotidine-5-fosphate-decarboxylase gene. Curr. Genet., 11, 499-503, 1987.

9. Griffin, D.H. Fungal Physiology. Wiley-Liss, New York, USA, 1994

10. Haq, I.U; Ali, S.; Qadeer, M.A.; Iqbal, J. Effect of copper íons on mould morphology and citric acid productivity by Aspergillus niger using molasses based media. Process Biochem., 37, 1085-1090, 2002.

11. Kerridge, D. Fungal dimorphism: a sideways look. In: Bossche, H.V.; Odds, F.C.; Kerridge, D. (Ed). Dimorphic fungi in biology and medicine. New York: Plenum Press, 1993, p.3-10.

12. Kirimura, K.; Sarangbin, S.; Rugsaseel, S.; Usami, S. Citric acid production by 2-deoxyglucose-resistant mutant strains of Aspergillus niger. Appl. Microbiol. Biotechnol., 36, 573-577, 1992.

13. Kisser, M.; Kubicek, C.P.; Rohr, M. Influence of manganese on morphology and cell wall composition of Aspergillus niger during citric acid fermentation. Arch. Microbiol., 128, 26-33, 1980.

14. Madi, N.; Mcneil, B.; Harvey, L.M. Effect of exogenous calcium on morphological development and biopolymer synthesis in the fungus Aureobasidium pullulans. Enzymol. Microbiol. Technol., 21, 102107, 1997. 
15. Metz, B.; Kossen, N.W.F. The growth of mould in the form of pellet. Biotech. Bioeng., 19, 781-799, 1977.

16. Netto, G.S.O.F.; Rosato, Y.B. Influence of nitrogen source on development of two strains of Aspergillus nidulans. Rev. Microbiol., 18(1), 83-86, 1987.

17. Paula, C.R.; Purchio, A.; Gambale, W.; Correa, B. Dimorphism of Scopulariopsis brevicaulis: morphogenesis of the mould to yeast phase. Mycopathology, 100, 69-74, 1987.

18. Pera, L.M.; Callieri, D.A. Influence of calcium on fungal growth and citric acid production during fermentation of a sugarcane molassesbased medium by a strain of Aspergillus niger. World J. Microbiol. Biotech., 15, 647-649,1999.

19. Pitt, J.I. The genus Penicillium and its teleomorphic states Eupenicillium and Talaromyces. Academic Press, New York, 1979.
20. Rugsaseel, S.; Kirimura, K.; Usami, S. Citric acid accumulation by cycloheximide-sensitive mutant strains of Aspergillus niger. Appl. Microbiol. Biotech., 45, 28-35, 1996.

21. Shu, P.; Johnson, M.J. Effect of the composition of the sporulation medium on citric acid production by Aspergillus niger in submerged culture. J. Bacteriol., 54, 161-167, 1947.

22. Tomlinson, N.; Campbell, J.J.R.; Trussel, P.C. The influence of zinc, iron, copper and manganese on the production of citric acid by Aspergillus niger. J. Bacteriol., 59, 217-227, 1950.

23. Torralba, S.; Heath, J.B. Cytoskeletal and $\mathrm{Ca}^{2+}$ regulation of hyphal tip growth and initiation. Curr. Develop. Biol., 51, 135-187, 2001.

24. Turner, G.; Balance, D.J. Cloning and Transformation in Aspergillus in gene Manipulations in Fungi (Ed) Bennett, J.W.; Lasure, L.L. Academic Press, Orlando USA, 1985. 